\title{
Opening discourses of citizenship education: a theorization with Foucault
}

\author{
Katherine Nicoll, Andreas Fejes, Maria Olson, Magnus Dahlstedt and Gert Biesta
}

\section{Linköping University Post Print}

\section{Tweet}

N.B.: When citing this work, cite the original article.

This is an electronic version of an article published in:

Katherine Nicoll, Andreas Fejes, Maria Olson, Magnus Dahlstedt and Gert Biesta, Opening discourses of citizenship education: a theorization with Foucault, 2013, Journal of education policy, (28), 6, 828-846.

Journal of education policy is available online at informaworldTM:

http://dx.doi.org/10.1080/02680939.2013.823519

Copyright: Taylor \& Francis (Routledge): SSH Titles http://www.routledge.com/

Postprint available at: Linköping University Electronic Press http://urn.kb.se/resolve?urn=urn:nbn:se:liu:diva-95915 


\title{
Opening Discourses of Citizenship Education: A Theorization with Foucault
}

Katherine Nicoll, University of Stirling

Andreas Fejes, Linköping University

Maria Olson, Stockholm University

Magnus Dahlstedt, Linköping University

Gert Biesta, University of Luxembourg

Published in Journal of Education Policy 2013, 28(6), 828-846.

\begin{abstract}
We argue two major difficulties in current discourses of citizenship education. The first is a relative masking of student discourses of citizenship, by positioning students as lacking citizenship and as outside the community that acts. The second is in failing to understand the discursive and material support for citizenship activity. We thus argue that it is not a lack of citizenship that education research might address, but identification and exploration of the different forms of citizenship that people already engage in. We offer a fragmentary, poststructuralist theorization oriented to explore the 'contemporary limits of the necessary', drawing on specific resources from the work of Michel Foucault and others for the constitution of local, partial accounts of citizenship discourses and activities, and exploration of their possibilities and constraints. We argue this as a significant tactic of theorization in support of an opening of discourses of citizenship and in avoiding the discursive difficulties that we have identified. Our theorization then is significant in its potential to unsettle discourses that confine contemporary thought regarding citizenship education, and support exploration of what might be excessive to that confinement.
\end{abstract}

Keywords: citizenship education, active citizenship, discourse, power, statement, condition of possibility, democracy

\section{Introduction}

The problem of not enough citizenship has been on the agenda of politicians, policy makers and civic organisations over the past decades in the field of education and more widely (Isin and Wood 1999). In some contexts, concern for a revitalisation of citizenship and citizenship education has been fuelled by arguments of inadequate or decreasing levels of civic participation and political involvement (Putnam 2000, Council of Europe 2005). A lack of social cohesion and social exclusion are seen to be related to this 'problem' (cf. Nelson and Kerr 2006, Schultz et al. 2010, Schmeets and Coumans 2013), even though there appears evidence from some contexts that participation and involvement is changing rather than decreasing (Hilton et al. 2010, Schmeets and Coumans 2013). Nelson and Kerr identify social cohesion or civic engagement as the key policy motivation for promoting citizenship education and driving change in specific countries: 'the Netherlands, Republic of Ireland, Hungary and England' (2006, v) ${ }^{1}$. In these nations, policy discourses tend to represent citizenship education as a 'lever' for cohesion or engagement. In the International Civic and Citizenship Education Study (ICCS) (Schulz et al 2010), there is suggested to be an increasing focus on the role in civic and citizenship education in supporting social and

\footnotetext{
${ }^{1}$ Nelson and Kerr (2006) carried out an international review of active citizenship policy definitions and orientations in curriculum and assessment frameworks internet archive (INCA) countries: Australia, Canada, England, Hungary, Italy, Japan, the Netherlands, New Zealand, Northern Ireland, the Republic of Ireland, Scotland, Singapore, Spain, the USA and Wales. Data on active citizenship was gathered through questionnaire and through discussions at an international seminar in 2006.
} 
community cohesion . Social cohesion is understood as an important 'domain' for study and topic for the curriculum in many countries. At the same time, social inclusion has been one of the aims of Phase 4 (2006-2009) of the Council of Europe project for education for democratic citizenship (Keating, Ortloff and Philipou 2009). Although whether or the extent to which civic participation and political involvement is insufficient or decreasing is contested, the participation and involvement of citizens in political and social citizenship practices is argued as important for the legitimacy of democratic governance and to crucially depend on the extent to which democratic structures and practices are supported and 'owned' by citizens.

There are difficulties inherent in dominant academic and wider debate and projects regarding citizenship education. First, what appears relatively ignored is that citizenship is already enacted by those students who are the target of citizenship education - they already practice citizenship in a variety of ways. Thus, where in policy documents citizenship education is commonly positioned as a preparation for life, this ignores that students may well be citizens (legally), and even as children are already shaped as citizens through their knowledge and action in a variety of ways. The policy language of citizenship education positions people as 'needing' the knowledge, values and competencies for citizenship and further development, which is to position them outside the existing community of citizens who act (Biesta 2011b, Olson 2009, 2012a) - as excluded and lacking in a way that they have to overcome. This masks understandings of citizenship and activities carried out by citizens. It implies a problem of not enough citizenship and that this inherently lies within the individual. More learned capacities and dispositions for the individual, more preparation for activity, appear to be the solution to this construction.

A second major difficulty is that while the emphasis for students is on learning understandings, capacities and dispositions for citizenship through citizenship education, their potential to be active as citizens is also socially and materially enabled and constrained. Discursive and material resources (Wilson 2000, Elm-Larsen 2006), support specific forms of activity. Although current citizenship research explores the motivations and contexts for activity to be encouraged, and there is some evidence that schooling for citizenship does increase later engagement in citizenship activity (i.e. related to volunteering, Wilson 2000), the emphasis on citizenship education moves attention from the wider support for activities which may be important in people acting or not acting. Research shows, for example, that various social resources and participants cultural capital support activity. However, what will act as a social resource, for example, in volunteering, appears to be difficult to identify prior to engagement in a specific activity (Wilson 2000). Furthermore, the picture is complex and situated, as some social resources, such as, for example, social ties and the existence of formal organizations, can act as both as support for and constraint on specific activities.

In this paper we argue for the opening of citizenship discourses and research for such opening. In support of this move we theorize a discursive and empirical approach for the exploration of students' understandings of what they do as citizens and of the discursive and material supports for these. We do not mean to go so far as to illustrate this approach with empirical material. However, we argue that its collection is a significant goal if the emergence and effects of citizenship discourses are to be understood in societies, or even, as a lesser goal, capture the imagination of adults and young people (Lawy and Biesta 2006, Olson 2012d). We suggest that a discursive and empirical approach is appropriate, in that empirical material would unsettle the discourses which confine contemporary thought 
regarding citizenship education, and allow a language to emerge over what might be excessive in that confinement. The citizenship education discourses currently promoted within the formal curriculum may cut across those that already exist, and act to limit in particular ways what can be 'acceptably' said as citizenship for young people. A main barrier to citizenship for young people and adults, therefore, may have been the way in which it has been dominantly explored and understood.

Our theorization is poststructuralist (cf. Foucault 1972, 1984, 2007, Dreyfus and Rabinow 1982, Marshall 1999). In discourse terms, particular prior discursive conditions contribute within a discursive terrain, enabling forms of citizenship activity. Central notions in our theorization are 'statements', 'conditions of possibility' and 'power'. The approach that we construct is practical in its concern to identify the limits and constraints to citizenship discourses in order that these might be put aside (Foucault 2007). It is homogeneous in its concern with citizenship as a realm of discursive practice, systematic in focus, and general in its potential to explore the discursive and material conditions that support situated discourses of citizenship and citizenship activity.

The paper is in three parts. First, in an overview of dominant discourses of citizenship and citizenship education we identify specific common themes. We argue these as constitutive of discursive regularities in citizenship education that position students as people not engaging enough with citizenship activity and failing to consider the means by which activities emerge. We propose a focus of attention on specific, 'local' discourses of citizenship. In a second section, we explore analytic resources necessary for this approach. In a third, we collect our thoughts and consider the originality, significance and limits of our theorization.

\section{Dominant citizenship and education discourses - a specific regularity}

Discourses of citizenship arise from particular contexts and have specific effects. A discourse includes what is said through speech or writing, but is more than this (Foucault 1972, 197). 'Citizenship' refers within one dominant discourse, to a relation between the individual and the state, guaranteeing citizens the legal status as full members of society along with certain rights and obligations (cf. Marshall 1950). It is through this legal or juridical discourse that citizenship is materially embedded within the structures, institutions and practices of any society that guarantees its citizens status, rights and obligations as citizens. Meanings of citizenship, in this juridical sense, are therefore found in both the language and material practices of democratic societies.

Discourses of citizenship are multiple and unstable and implicate associated social and legal systems and mechanisms for implementation. The legal discourse of citizenship is quite formal and limited. Citizenship discourses emerge not only to focus on individually oriented legal or juridical dimensions, but also on collective, social, cultural and participatory dimensions (Lister 1997, 2005, Isin and Turner 2002, Kymlicka and Norman 2000). Citizenship is then no longer conceived only in terms of a legal relation between the individual and the state but also in terms of individual and collective participation in citizenship. This participation is a 'total relationship, inflected by identity, social positioning, cultural assumptions, institutional practices and senses of belonging' (Werbner and Yuval-Davis 1999, 4). Discourses for participation focus attention on practices for active citizenship, in part as their effect. 
Today, much citizenship research focuses on how citizen subjectivities are created through participation in political, cultural, economic and working life (Birzea 2005), and explores practices - social and educative - though which this is achieved. This shift in emphasis from rights and obligations to participation and subjectivity construction has been fuelled by two concerns. First, a concern about limited or decreasing levels of civic participation and political involvement identified as characteristic of contemporary democratic societies (Dahlstedt 2009). This is argued to be particularly important if the legitimacy of democratic governance is to be upheld. It is considered to depend crucially on the extent to which democratic structures and practices are supported and 'owned' by citizens. Second, there is a concern for increasing social cohesion (Putnam 2000). This is seen to be possible through the inclusion in society of individuals and groups currently marginalized or excluded.

In the field of education in Europe a current dominant interpretation of citizenship is seen in the communication Making a European area of lifelong learning a reality where the European Commission has 'learning for active citizenship' as one of the three 'pillars' of activity to be developed and supported across Europe (European Commission 2001). The idea of active citizenship has become central in the European Union's [EU] policy approach to the development of citizenship and citizenship education (cf. Nelson and Kerr 2006, Ross 2008). Here social cohesion and inclusion can and should be supported through citizenship education and active participation (Keating 2009, Hansen 1998, Hedtke and Zimenkova 2012, Olson 2012b). The focus on the role of education in providing for citizenship emerges through EU policy and the culture of measurement promulgated through both European and national policy (see cf. Biesta 2010). However, there are critiques of this focus in the assumption that the problem is that of the individual citizen - a focus that avoids questions of power: 'The assumption of young adults as lacking the proper knowledge, skills, values and dispositions of citizenship capacity simply reinforces the conservative and neo-liberal notions of blaming individuals for their social malfunctioning without addressing power issues among individuals, groups and infrastructures' (Yeung, Passmore and Packer 2012, 76). The current policy emphasis reinforces a deficit model of citizenship. This takes attention away from the wider structural and power issues involved.

There are on-going and contested discussions in education policy, research and practice literature about the contribution of education to citizenship. These emanate from different disciplines and focus on questions about the shape and form of education for democratic citizenship with a variety of aims and approaches. A substantial body of this work deals both theoretically and philosophically with questions of the appropriate configuration of citizenship through education in democratic societies (cf. Gutmann 1987, Carr and Hartnett 1996, Crick 1998, 2007, McLauglin and Halstead 1999, Westheimer and Kahne 2004, Halstead and Pike 2006, Aspin 2007, Roth and Burbules 2007, Olson 2008, Peters, et al. 2008, Biesta 2011a). Research on citizenship education emerging from political theory stresses citizenship education in juridical terms - often in terms of a vertical or top down relationship between individuals and the state. Students are understood to learn how to participate in the public sphere as responsible democratic citizens, by understanding human and citizen rights in society and formal aspects of democracy (Callan 1997, Hahn 1998, Feinberg and McDonough 2003). Thus, it is in part through the disciplines that alternatives to this vertical relationship become articulated.

Other approaches focus on the work of the educational institution in the development of individual or interpersonal capacities to increase active citizenship. Citizenship in quite dominantly depicted within research and scholarly literature regarding citizenship and 
citizenship education as situated in concrete practices - constituted by individuals and groups in their daily living inside and outside of education (Björk 1999, Arnot and Dillabough 2000, Lister 2005, Öhrn, et al. 2011). This is considered as concern with horizontal relations. A growing body of empirical research focuses on both these dimensions, both vertical and horizontal, where concerns of the knowledge, skills, values and dispositions necessary for citizenship are considered together with those of the necessary educational processes, structures and support for participation (e.g. Ireland et al. 2006, Kelly 2006, Osler and Starkey 2006, Lund 2006, Biesta et al. 2009, Lopes et al. 2009, Osler 2009, Amnå et al. 2010). In a recent summary of research explaining citizens' participation, Yeung, Passmore and Packer (2012) group main factors supporting participation as: citizens' communication networks, social milieu and life satisfaction. Such research begins to illuminate the social and discursive factors that support citizenship behaviour.

Dominant scholarly and research literature has shifted from the earlier focus from citizens' rights and obligations towards that of students' participation and subjectivity construction. Current education policy projects for citizenship either construct the citizenship 'problem' as not enough citizenship education for the individual, or not enough active citizenship. Policy projects emphasise this construction by measuring (for example, as did Ireland et al. 2006) the extent to which education works to produce active citizens (Fejes and Nicoll 2008). In discourse terms, by focusing on citizenship education as the problem, citizenship becomes constructed in a specific way that leads quite 'naturally' to particular solutions as both logical and rational. Thus, policy discourses of a lack of civic and political activity appear to flow logically to arguments for the need to increase the participation of individuals and marginalized groups in democratic structures and practices, and thus to a particular form of citizenship education. This regularity stabilizes a view of education as a key solution to a 'democratic deficit' and at the same time cements an assumption that education is capable of solving social and political problems.

There appear few empirical and qualitative studies of the citizenship discourses of young people. Studies often presuppose categories for the elicitation of data or analysis about citizenship and therefore do not produce descriptions of discourses, as young people would articulate them. Lister et al. (2003, 236), pointing out this problem, and that 'compared with recent theoretical outpourings the empirical void is far from being filled', conducted a three year longitudinal UK study in the city of Leicester, aiming to help fill this gap. They characterized five overlapping discourses from their interviews. From the most to the least dominant, these were universal status, respectable economic independence, constructive social participation, social-contractual and, right to a voice. This was at a time when there was reported 'growing public concern about young people's relation to citizenship in the face of perceived apathy and disengagement' (Lister et al. 2003, 236). An 'ordinarily good' citizen was separated from an 'extra good' citizen, and identified through their interviews as in line with the earlier views of Dean and Melrose as 'someone who looks after other people.. someone who contributes to the community, and... someone who obeys the law and/or pays their taxes' (in Lister et al. 2003, 244). Actions of volunteering and improving the local area or community were some of the least often mentioned engagements (less than 10 percent) of the good citizen in these interviews. What was emphasised by over twothirds of the participants was 'a considerate and caring attitude towards others and a constructive approach towards and active participation in the community' (ibid., 244). This first aspect the authors identify as often expressed by participants as 'neighbourliness' and 
an informal 'looking out' for others. Indeed, one male participant, identified as an 'outsider', said ${ }^{2}$ :

I wouldn't call a good citizen like the kind who goes out to do charity and trying to raise money. That's not my version of a good citizen. Mine's like they'll help you out. They'll lend you something if you need it, and that's the way I see a good citizen... It’s like your neighbours. (ibid., 244)

This study and example is useful to the argument being built here. The quote is from a 19year-old male 'outsider' participant and does not give the impression of a lack of understanding of citizenship or apathy or non-engagement. It is not a discourse of active citizenship central to UK policy or those of the current citizenship curriculum in England with emphasis on volunteering. The point here is that these young people ('insiders' and 'outsiders') expressed views of citizenship able to be characterized as distinctive citizenship discourses. The study concludes that a 'dissident citizenship', as accepted non-violent protest, might ease the sense of oppression for 'outsiders' in being positioned through lack of employment, or criminal record as 'bad citizens'. As a small study, situated as it is within situated discourses, it exemplifies the potential for further and more detailed exploratory research.

A reframing of the problem and its solution may therefore be indicated - opening discourses of citizenship to the possibility of other ways of thinking. To investigate this might require engagement with situated and disqualified discourses of citizenship. It could mean a willingness to work with the differences and complexities of these and understand where factors producing and limiting discourses emerge. Although active citizenship and recognizing people as citizens are emphasised in educational policy, for instance in the UK and in Sweden (e.g., LTS 2002, DfES 2006, Prime Minister's Office 2000, The National Swedish Agency for Education 2010a, 2010b), citizenship practice is still predominantly considered to be the outcome of particular educational trajectories (Lawy and Biesta 2006). The focus is on more or better citizenship education and the inclusion of individuals, and not on the discourses and diverse activities already engaged in by young people or the social or material possibilities and limitations of the lived, discursive and material environment.

If the possibilities for citizenship are to be opened then one alternative could be a focus on these situated and disqualified discourses. These shape peoples' dispositions and rationalities for acting in particular ways - neighbourliness and looking out for others as well as volunteering etc., but also other forms of sociality including antisocial and illegal behaviour. Propensities to act are supported and limited through the discursive and material resources available; ways of thinking, social networks, money, community organizations and so forth (see LTS 2002, Devine 2003). They may include specific views regarding farright parties (Osler 2009). They may encompass factors such as those identified by Ireland et al. (2006): knowing and trusting people and having friends, the size of the local community, the availability of activities and feeling safe and having access public spaces. Working with the idea of opening up the discursive space in situated contexts we think

\footnotetext{
2 "Given the salience of paid work to contemporary characterisations of citizenship, the group was stratified according to 'insider' and 'outsider' status as a proxy for social class. 'Insiders' conformed with a stereotypical model of the 'successful' young person as on the route through 'A'-levels and university and into graduate-type employment; 'outsiders' fell well outside it, with few or no qualification and a record of unemployment for most of the time since leaving school” (Lister et al. 2003, 236)
} 
might be less dangerous than the normalization of discourses that we suggest tends towards a narrowing of discourses and closure.

The dominant focus on preparation for citizenship substantially ignores the discursive and material resources that help make citizenship possible in various ways. Some research exists where students are asked for their opinions about citizenship, and how they define themselves as citizens (Tursunovic 2004, Ekman 2007, Niklasson 2007, and Olson 2012b). Some work develops citizenship 'voice' with young people (France 1996, Yates and Youniss 1998, Hall et al. 1999, 2000), but most often this does not go further. By beginning with students' existing discourses and practices and engaging in questions of the means for their emergence, this could result in an altered way of thinking. It would require thinking of citizenship from discursive practices, the means for their specific emergence and effects.

We propose then a focus of attention on specific, situated discourses of citizenship and the discursive and material supports to citizenship activities. We argue that it is not only a lack of citizenship that education might address but also the identification of and support for the different forms of citizenship that people already engage in. In this respect, one might then have anti-social citizenship - e.g. riots against the UK poll tax, or the recent events in Spain and Greece - but these possibilities then emerge as available for discussion and debate. This is a significant tactic, with potential to open discourses of citizenship, and avoid the difficulties we have identified.

\section{A theorization with Foucault}

This idea of opening discourses of citizenship is in itself not new. Theoretical and philosophical approaches as we have noted do allow for reflexive engagement with questions of the appropriate configuration of citizenship through education in democratic societies. Current research in this vein is productive. For example, Social Critical Theory approaches to citizenship education arising from the Marxism of the Frankfurt School have been particularly fruitful in supporting projects for community development, participatory action research and rural development in many countries (Johnston 2005). The difficulty with theory underpinning such projects has been held in a necessary rejection of dominant economic relations of power and in beginning with the primacy of class struggle and the material and social existence of knowledges (Nicoll 2008). Our suggestion requires a question of power relations in the emergence of dominant discourses and the discourses that are marginalized in this. It moves in order that questions of the constitution of meanings of citizenship within power relations and their effects can be put.

Our proposal then offers an alternative to emancipatory notions by requiring a suspension of any question of the 'real' in citizenship or democracy (Olson 2009). Here there might emerge openness within discourses to questions of citizenship through an avoidance of a normative focus on strengthening a collective moral character. This is in order that questions of the constitution of 'moral character' might be asked, in a widening of the possibilities for question. For Olson (one of the authors here), the problem is a curriculum focus 'which entails a fixed set of nationally encompassing moral skills and values whose application is considered to serve as the appropriate way for the individual to fulfil her democratic life' (Olson 2009, 77). Embracing alternative forms of democratic citizenry to those narrowly prescribed through a generalized curriculum is necessary if a more open democracy is to be possible. Without this space for and as democracy, democracy cannot emerge: 
Individuals and groups whose experiences, values and (choosing) attitudes are not found to be compatible with this 'residenced' democracy thus tend to be excluded from a decent, recognisable democratic citizenship, or for some reason are considered to be not-yets in respect to such democratic existence (Olson 2009; 77).

It is in the spirit of this kind of suspension, in openness to questions of the constitution of citizenship that we propose an alternative theorization.

A specific poststructuralist and discursive approach that draws together some resources from the work of Michel Foucault (1972, 1984 and 2007), Dreyfus and Rabinow (1982) and Marshall (1999) we propose as potentially helpful. Although we emphasize this as 'fragmentary, incomplete and the local, indeterminate and partial' (Brosio 2005), this does not suggest that the 'local' implies that it is peripheral or without potential for effect. Rather, we consider that the difficulties identified are considerable in their maintenance of a particular regime of power. Although this is necessary and productive in our times - we do not suggest a relinquishing of this - by narrowing the focus of citizenship understandings to those emerging through policy, educational and other formal institutions and research may be more dangerous than not. Thus, where those such as Brosio (2005) suggest that poststructuralist resources are inadequate to the task of overthrowing such relations of power, we are not convinced by such arguments - this in any case is not our aim.

For a theorization, we need to construct a way of treating citizenship discourses that have been marginalized with just as much attention as others appearing to have more significance or authority. We want to explore the discourses of citizens. 'Citizenship' is therefore to be that which is identified by people in situated discursive contexts, as well as more authoritatively elsewhere within research, institutions and policies. For this, we consider resources from Foucault's The Archaeology of Knowledge (1972) where he is concerned with the knowledge of the human sciences. Here Foucault makes a distinction between the speech act and the 'statement' (see Dreyfus and Rabinow 1982, 45). What he identified as his concern were 'statements' (énoncés) of discourse, as that which is said and written seriously. We want to explore the possibility of deploying this notion outside the domain of the authoritative knowledge of citizenship as a human science and formal policies and institutions. Statements are serious in that they are based on an accepted method for serious truth claims: 'Any speech act can be serious if one sets up the necessary validation procedures, community of experts, and so on' (Dreyfus and Rabinow 1982, 48). What makes a statement serious, are the validation procedures that accompany them and turn them into 'objects to be studied, repeated, and passed on to others' (Dreyfus and Rabinow 1982, 48). However, our concern is not the validation procedures of citizenship as science as such, but those of statements taken seriously elsewhere, and their relation to everyday utterances or speech acts. We want to blur a boundary between serious statements from the human sciences and those commonly emphasised and emanating elsewhere, in order that we might explore their interconnections and relations, but also to give more status to these latter, and their discursive and material conditions..

'Statements' define discourses to which they recognizably contribute: 'the term discourse can be defined as the group of statements that belong to a single system of formation' (Foucault 1972, 107). A statement of citizenship is then what is said recognizably of citizenship within a specific discourse, but it is also more than this. Statements are what can be taken seriously in that they conform to 'rules' of discourse. Thus, these might be 
statements found in policy texts, scholarly work, politicians' announcements or other authoritative 'texts' on citizenship, or more widely. These, as they are shaped through such rules; the bodies of knowledge, theories and rationalities from which statements draw, the concepts that these require, the conventions of speech and writing depended upon, the social institutions, networks and the formal spaces required for this, and the roles determining who can speak, of what, and in what manner, etc. (cf. Nicoll 2008). Statements are serious when are acceptably realized through these sorts of rules.

However, statements of citizenship emerge elsewhere, formulated through such rules, although not perhaps the same ones. Statements, we argue, are not only the prerogative of people who speak through formal discourses in 'recognized' places. Foucault separates out serious statements (Nicoll 2008), but in his focus appears to reject those elsewhere. This boundary appears difficult to hold both in terms of a focus on the human sciences and in the performativity of language. James Marshall, exploring this latter in institutional contexts, concludes: 'Foucault should have concentrated more on these ordinary everyday utterances and the force which they carry, for the force is not merely in the underlying power/knowledge but also in the uses of language in everyday speech acts' (Marshall 1999, 316). Marshall argues that this has important implications for investigations of the performativity of language in education settings, and, we argue here, for citizenship discourses. Although statements of the human sciences are 'special' in that they gain rarefaction through rules lying within and behind discourses, alternative rules support statements and speech elsewhere. These may emanate from other 'texts', discourse groups and cultures - Greenpeace, religious texts, far-right organizations, marketing, the media, the family, and so forth. The performativity of language in part emerges through peoples' various allegiances within such discourses. Speech draws on rhetorical conventions for the 'building' of the facticity of description, and these emerge as regularities, and relations of these, within potentially recognizable discourses (cf. Potter 1996, Edwards et al. 2004).

This possibility of statements as more generally everyday utterances, then allows openness to the exploration and analysis of citizenship discourses. Statements emerge, as these are constituted by principles or rules that lie in some sense within or behind discourses (Dreyfus and Rabinow 1982). Rules are apparent, for example, when we consider that discourses 'constrain what can count as objects, what sorts of things can seriously be said about them, who can say them, and what concepts can be used in the saying' (Drefyus and Rabinow 1982,71). There are rules that lie within or behind specific discourses that support the proliferation of what can be seriously said. People therefore may talk about an object 'citizenship' or not in their everyday lives. Thus, it is through the analyses of what is said by people within specific discourse settings that much may be understood of citizenship in those settings. What people think as citizenship, or otherwise, may be quite other than what others think it 'should' be.

Statements are nodes in discursive networks that are systems of references to other texts, sentences and books (Foucault 1972). They are made in speech and writing, but they are not entities bounded by a speech, book or paper in itself. These networks and rules constitute the parameters for our thoughts, rationales, activities and institutions. As a familiar example, Dreyfus and Rabinow (1982, 66, emphasis in original) explicate the functioning of such rules in constituting and maintaining university life:

What organizes the institutional relations and the thinking is finally the system of rules which govern what sort of talk about education (and which talkers) 
can, in a given period, be taken seriously. It is these rules 'governing' what can be seriously said that, counter-intuitive as it may first seem, ultimately 'effect' or 'establish' university life as we know it.

Statements are autonomous, as what is said is made serious through reasoned argument, interrogation or empirical confirmation elsewhere: '[b]y passing the appropriate tests statements can be understood by an informed hearer to be true in a way that need make no reference to the everyday context in which the statement was uttered' (Dreyfus and Rabinow 1982, 48). Thus, there are various forms of 'tests' that operate in relation to the rules of discourse mobilized through particular institutional forms or discourse groups within society. These are used to gauge whether or not what is said at any one time is serious, through its conforming to those rules. Hence, for example, the peer review of statements of citizenship within academic discourse, and the system for the warranting of the truth of what is said regarding citizenship, is specific to that sort of discourse and might be understood by an 'informed hearer' as that sort of test.

In this paper, we are interested in theorizing the regularities of everyday utterances and statements as constitutive of citizenship discourses. We propose that empirical and discursive investigation is appropriate to an aim to unsettle discourses that appear to confine contemporary thought regarding citizenship education. The analysis (of discursive rules, objects and rhetorical regularities of description and their relations) could offer alternative understandings of citizenship and citizenship education - allowing a language to emerge over what might be excessive in its confinement.

Foucault's notion of power became important in his later genealogical work, and it may be in exploration of the regularities of citizenship discourses that we may come to see how power operates through them in our societies: 'Power exists only when it is put into action' (Foucault, in Dreyfus and Rabinow 1982, 789). Citizenship discourses are a vehicle for the exercise of power in societies, in shaping societies and subjectivities. Thus, where a student or citizen describes citizenship, power is exercised through the mobilization of knowledge and its internalization in the constitution of the subject. The exercise of power produces subjects choosing to act through the field of possible responses opened up through specific discourses of citizenship:

a power relationship can only be articulated on the basis of two elements which are each indispensable if it is really to be a power relationship: that 'the other' (the one over whom power is exercised) be thoroughly recognized and maintained to the very end as a person who acts; and that, faced with a relationship of power, a whole field of responses, reactions, results, and possible inventions may open up. (Foucault in Dreyfus and Rabinow 1982, 789)

Thus, as an example of the exercise of power here, top-down by a government, the UK Labour party deployed citizenship discourses in 1997, in attempts to reconstruct the responsible and moral citizen (cf. Rose 1999; Jerome 2012; Kisby 2012). Citizenship education emerged to emphasise 'active citizenship' within schools and post-school colleges in the UK. In this attempts were made to re-order citizens as subjects, through arguments and activity for the privatisation of specific welfare organizations as outside the social state, and in the shaping of citizens who would take up volunteering activities within communities. However, how the field of possible responses was reconfigured, and how people responded, is less clear. A focus on the exercise of power and local discourses thus 
would allow exploration of local re-configurations and the complexities involved. Of course, academic research tends to focus on this kind of top-down deployment, perhaps as it is easy to identify, and marks change. Power is exercised in similar ways through wider discourse groups. Citizenship discourses may be aligned in support of rationalities for social integration (through policies and the curriculum for example), but also may support or challenge and reconfigure the existing social and political order (through citizens' discourses emanating elsewhere) (cf. Isin and Nielsen 2008). In this way 'citizenship' entails meanings and configurations inscribed through discursive contexts and events, as they are enacted widely by individuals, groups and institutions. Citizenship is a dispersed, fragmented, regime of government (cf. Cruikshank 1999, White and Hunt 2000, Hindess 2002), through which the exercise of power is not unidirectional or emanating from one discourse location, or with objects or boundaries that are secure or stable.

\section{Collecting thoughts}

To pause then here, citizenship is constituted in and through a complex, heterogeneous, fragmented, discursive 'regime', governing what people in different locations say they or others may do, achieve, hold or receive as citizens in the specific situations that they identify. Meanings of citizenship can be analysed as statements, in terms of the rules of their acceptance and discursive functioning. They can be analysed in terms of the rhetorical regularities entailed in the descriptions of citizenship offered by citizens, of the speaking subject constructed, the objects and concepts made available, the rationalities and activities produced, and so forth. They can be analysed in terms of the field discourse as that delineating possible action, the effects of the power relations produced and maintained, and as resources that help make specific actions possible. This shifts the focus from the institution of citizenship and the citizen as agent, to discourses and acts of citizenship and the power relations that these imply and maintain. In this, citizenship is not universal or unified; it is discursive, heterogeneous, dynamic, fragmented and historically changeable (cf. Cruikshank 1999, Olson 2012c). It is through these kinds of theorization, we argue, that citizenship might be explored. Citizenship is as much about the wider discourses and practices of civic engagement, as it is policy or other institutionalized discourses, and the two are not necessarily aligned.

One might pose a normative and critical question. Education institutions have been normative in their function throughout Modernity, and opening discourses up to research in this way could be argued to bring hitherto disqualified discourses 'into the fold', so to speak - to act in their normalization. Any suggestion for the provision of 'stabilized forums' within a citizenship or educational curriculum (Phillips 2002, 324), in this sense, may lead merely to a readjustment of power relations. However, the question itself seems to imply that normalization might be a bad thing, and that is not what we have been arguing.

The object for us is not to act in any reinforcement of normalizing relations or in the reversal of power relations, as might be to aim in oppositional or emancipatory practices. This would merely suggest the replacement of one set of norms for another as reform, or a replacement of one set of power relations for another. For us, the point of undecideability is what Foucault and we have in mind: '[f]reedom be conceived not as the reversal of power relations or the introduction of reforms, but the uncertain point of reversibility' in thought (Phillips 2002, 336). Foucault appears to go further. He raises questions over the forms of constraint as aspects of thought that we might dispense with (2007), in the forging of a material freedom. This is for him an open question and a question of ethics and choice. We have then aimed to 
reach this point of reversibility in thought and openness of thought to suggestion - a point at which ethics and choice emerge as questions to address.

As Butin (2001) argues, Foucault's notion of resistance within power relations is inherent in the dynamic between acting agents, through which we unavoidably create ourselves as subjectivities. To respond to any question over the justification for our proposition would be to appeal to a normative framework (in articulating an answer as good or bad). Instead, we, as Foucault, implicate situated explorations of struggle, to find out not reality or truth, but what this says about what is being silenced and possible as transformation. The point is not that some relations of power are good and others bad, but that some are more or less dangerous. The less dangerous have greater potential for transformation within normative forces. Where there are opportunities for resistance to be present within normalizing,subjugating and productive processes, there is then less danger. Where uncertainty is great, there is greater opportunity for transformation.

I would like to suggest another way to go further towards a new economy of power relations, a way which is more empirical, more directly related to our present situation, and which implies more relations between theory and practice. It consists of taking the forms of resistance against different forms of power as a starting point ... in order to understand what power relations are about, perhaps we should investigate the forms of resistance and attempts made to dissociate these relations. (Foucault, in Dreyfus and Rabinow, 1982, 210-211)

Empirical evidence may have appeared to suggest a lack of civic and political activity from citizens, and thus the problem of not enough citizenship has emerged to be addressed. It has perhaps seemed logical to accept arguments from policy and civic organizations for an increase in the participation of individuals and marginalized groups in democratic structures and practices. These arguments emerge from and intersect powerfully with a notion of social cohesion from a specific theorization. Perhaps partially, in this allegiance across discourses, the arguments and rationality have seemed plausible. It appears logical to accept arguments for the need to increase the participation of individuals and marginalized groups in democratic structures and practices, whether or not they are already participating in their own way, even as disaffected or refusing. Policy language of citizenship education positions people quite naturally as therefore needing the knowledge, values and competencies for citizenship and further development of these. The rationale is perhaps also easy to accept as education generally has this sort of normative function. However, this also stabilizes a view of education as a key solution to a 'democratic deficit' and cements an assumption that education is problematic and/ or capable of solving social problems.

The attempt of this paper has been to suggest a theorization for citizenship as a means to promote thought over quite different research as (self-) educative work. Although we cannot recommend this as a 'good' thing, we can set ourselves a task to begin with research that will explore students' discourses of citizenship and engage in questions that could result in altered thinking and new possibilities for theorizing. It requires thinking of educating from situated citizenship discourses and possibilities for them. This theorization then might temporarily and partially displace or overstep previous normative discursive limits. This would be through inquiry directed towards citizenship discourses as those of Enlightenment rationality, but neither for or against this rationality (Foucault 1984, in Olssen 2003). It "will be oriented toward the "contemporary limits of the necessary," that is, toward what is not or is no longer indispensable for the constitution of ourselves as 
autonomous subjects' (Foucault 1984, in Olssen 2003: 87). Thus, we argue that although dominant discourses of citizenship support our normalization as autonomous subjects, critique could be directed to the analysis of the limits of what is necessary for our maintenance as autonomous, so that limits within our thought that we can dispense with might be put aside.

What we have intended here is to work 'against the solidification of the dangerous structures we create in what can no longer be imagined as the innocent pursuit of knowledge' (Foucault, in Lather 2006, 36). Heavily normalizing forms of citizenship education are, we think, dangerous. We are arguing for spaces to capture the play of dominant and disqualified discourses 'vying for legitimacy' (Lather 2006, 40). This proposal as theorization acts to 'open up a history of what contains thought and how thought is both shaped by and excessive to that containment' (Lather 2006, 41). Our move is toward openness to the recognition of alternatives.

Although we have emphasized the local, fragmentary, incomplete, indeterminate and partial in our analysis (Brosio 2005, 73) this has not implied that we think it peripheral or without potential for effect. Rather, the boundaries overstepped are significant and considerable in their maintenance of a particular regime of power. In making our suggestion we contribute then our own statement for the opening of citizenship and democracy, as an offer towards questions in such opening.

\section{References}

Amnå, E., Arensmeier, C., Ekman. J., Englund, T. and Ljunggren, C., 2010. "Skolornas institutionella karaktär och elevernas medborgarkompetens: En jämförelse av olika kommunala och fristående skolor över tid och rum”. Statsvetenskaplig Tidskrift 112 (1).

Arnot, M. and Dillabough J-A. eds, 2000. Challenging Democracy. International Perspectives on Gender, Education and Citizenship. London: Routledge Falmer.

Aspin, D. N., ed., 2007. Philosophical Perspectives on Lifelong Learning. Dortrecht, The Netherlands: Springer.

Biesta, G. J. J. and Lawy, R., 2006. "From Teaching Citizenship to Learning Democracy: Overcoming Individualism in Research, Policy and Practice”. Cambridge Journal of Education 36 (1): 63-79.

Biesta, G. J. J., 2010. Good Education in an Age of Measurement: Ethics, Politics, and Democracy. Boulder, CO: Paradigm.

Biesta, G. J. J., 2011a. “The Ignorant Citizen: Mouffe, Ranciére and the Subject of Democratic Education”. Studies in Philosophy and Education, 30 (2): 141-153.

Biesta, G., J. J., 2011b. Learning Democracy in School and Society: Education, Learning and the Politics of Citizenship. Rotterdam: Sense Publishers.

Birzea, C., 2005. "European Citizenship as a Cultural and Political Construct”. Journal of Social Science Education, 3. Accessed 15 August. http://www.jsse.org/2005/2005-3/birzeaeuropean-citizenship-as-a-cultural-and-political-construct

Björk, G., 1999. Att Förhandla sitt Medborgarskap: Kvinnor som kollektiva politiska aktörer i Örebro 1900-1950. Örebro: Örebro Universitet.

Brosio, R. 2005. "Review Essay. Does Poststructuralist Thought Represent a Challenge to the Neoliberal Project and Actually Existing Capitalism? A review of Michael A. Peters, 2001, Poststructuralism, Marxism, and Neo-liberalism: Between Theory and Politics. Lanham, Maryland: Rowman and Littlefield Publishers”. Studies in Philosophy and Education 24: 6378. 
Butin, D. W. 2001. "If This is Resistance I Would Hate to See Domination: Retrieving Foucault's Notion of Resistance Within Educational Research". Educational Studies, 32(2): 157-176.

Callan, E., 1997. Creating Citizens. Oxford: Oxford University Press.

Carr, W. and Hartnett, A., 1996. Education and the Struggle for Democracy. The Politics of Educational Ideas. Buckingham/Philadelphia: Open University Press.

Council of Europe 2005 Launch Meeting of the Forum on the Future of Democracy, Meeting of the Council of Europe Forum on the Future of Democracy - Warsaw, 3-4, November. Accessed $29 \quad$ April. http://www.coe.int/T/E/Com/Files/Events/2005democratie/20051104_conclusions.asp

Crick, B., 1998. Education for Citizenship and the Teaching of Democracy in Schools: Final Report of the Advisory Group on Citizenship. London: QCA.

Crick, B., 2007. "Citizenship: The Political and the Democratic”. British Journal of Educational Studies 55(3): 235-248.

Cruikshank, B., 1999. The Will to Empower: Democratic Citizens and Other Subjects. New York: Cornell University Press.

Dahlstedt, M., 2009. Aktiveringens politik: Demokrati och medborgarskap för ett nytt millennium. Malmö: Liber.

Devine, F., 2003. A Qualitative Study of Democracy and Participation in Britain, 1925-2003.

ESDS Database. Accessed 24 August:

http://www.esds.ac.uk/findingData/snDescription.asp?sn=5017

DfES (Department for Education and Skills), 2006. Further Education: Raising Skills, Improving Life Chances, Norwich: The Stationary Office.

Dreyfus H. and Rabinow P., 1982. Michel Foucault: Beyond Structuralism and Hermeneutics, with an Afterword by Michel Foucault. London: Havester Wheatsheaf.

Edwards, R., Nicoll, K. Solomon, N. and Usher, R. 2004. Rhetoric and Educational Discourse: Persuasive Texts, London: Routledge

Ekman, T., 2007. Demokratisk kompetens: Om gymnasiet som demokratiskola. Göteborg: Göteborg University Press.

Elm-Larsen, J. 2006. "Governing the Spaces on the Margins of Society”. In Marston, G. \& McDonald, C., eds. Analysing Social Policy: A Governmental Approach. Cheltenham: Edward Elgar.

European Commission, 2001. Communication From the Commission: Making a European Area of Lifelong Learning a Reality. Brussels: European Commission.

Feinberg, W., and McDonough, K., 2003. Citizenship and Education in Liberal-Democratic Societies: Teaching for Cosmopolitan Values and Collective Identities. Oxford: Oxford University Press.

Fejes, A and Nicoll, K. (eds), 2008. Foucault and Lifelong Learning: Governing the Subject. London: Routledge.

Foucault, M., 1972. The Archaeology of Knowledge. New York: Harper.

Foucault, M. 1982. "Afterword, The Subject and Power", in Dreyfus H. and Rabinow P. Michel Foucault: Beyond Structuralism and Hermeneutics, with an Afterword by Michel Foucault. London: Havester Wheatsheaf.

Foucault, M., 1984. "What is Enlightenment?” (trans. C Porter). In P. Rabinow (Ed,), The Foucault Reader, 31-50. New York: Pantheon.

Foucault, M., 2007. The Politics of Truth. Los Angeles: Semiotext(e).

France, A., 1996. "Youth and Citizenship in the 1990s", Youth and Policy, 43: 28-43.

Gutmann, A., 1987. Democratic Education. Princeton, N.J.: Princeton University Press.

Hahn, C., 1998. Becoming Political: Comparative Perspectives on Citizenship Education. Albany: State University of New York Press. 
Hall, T., Coffey, A. and Williamson, H., 1999. "Self, Space and Place: Youth Identities and Citizenship”. British Journal of Sociology of Education, 20 (4): 502-513.

Hall, T., Williamson H. and Coffey A., 1998. "Conceptualizing Citizenship: Young people and the Transition to Adulthood”, Journal of Education Policy 13(3): 301-315.

Hall, T., Williamson, H. and Coffey, A., 2000. "Young People, Citizenship and the Third Way: a Role for the Youth Service?” Journal of Youth Studies, 3 (4): 461-472.

Halstead, J. M. and Pike, M. A., 2006. Citizenship and Moral Education: Values in Action. London: Routledge.

Hansen, P., 1998. "Schooling a European Identity: Ethno-cultural Exclusion and Nationalist Resonance within the EU 23 Policy of 'The European Dimension in Education'”. European Journal of Intercultural Studies, 9 (1): 5-23.

Hedke, R. and Zimenkova, Z. eds., 2012. Education for Civic and Political Participation: A Critical Approach. London: Routledge.

Hilton M., McKay J., Crowson N and Mouhot J-F, 2010. "'The Big Society': Civic Participation and the State in Modern Britain”, History and Policy. Accessed 8 May. http://www.historyandpolicy.org/papers/policy-paper-103.html. Initially published as: Civic Participation and Social Responsibility, Briefing paper for meeting with Strategy Unit of Cabinet Office, 15 June 2010.

Hindess, B., 2002. “Neo-liberal Citizenship”. Citizenship Studies, 6 (2): 127-143.

Ireland, E., Kerr, D. Joana Lopes, et al., 2006. Active Citizenship and Young People: Opportunities, Experiences and Challenges In and Beyond School. National Foundation for Educational Research. $\quad$ Accessed $26 \quad$ June https://www.nfer.ac.uk/nfer/publications/CEE06/CEE06_home.cfm?publicationID=427\&title =Active\%20citizenship\%20and\%20young\%20people:\%20opportunities, $\% 20$ experiences $\% 20$ and\%20challenges\%20in\%20and\%20beyond\%20school\%20citizenship\%20education.\%20L ongitudinal\%20Study:\%20fourth\%20annual\%20report

Isin, E.F. and Nielsen, G.M., 2008. “Introduction”. In E.F. Isin and G.M. Nielsen, eds. Acts of Citizenship. New York: Zed Books.

Isin, E.F. and Turner, B., eds, 2002. Handbook of Citizenship Studies. London: Sage.

Isin, E.F. and Wood, P.K.,1999. Citizenship and Identity. London: Sage.

Jerome, L. 2012. England's Citizenship Education Experiment: State, School and Student Perspectives. London: Continuum.

Johnstone R. 2005. "A Framework for Analysing and Developing Adult Learning for Active Citizenship”. In Widemeersch, D. Stroobants, V. Bron Michal Jr. (eds.), Active Citizenship and Multiple Identities: A Learning Outlook, European Studies in Lifelong Learning and Adult Learning Research. Frankfurt am Main: Peter Lang.

Keating, A, Ortloff, D. H. and Philipou, S, 2009. "Citzenship Education Curricula: The Changes and Challenges Presented by Global and European Integration", Journal of Curriculum Studies, 41 (2): 145-158.

Keating, A. 2009. "Educating Europe's Citizens: Moving from National to Post-national Models of Educating for European Citizenship”. Citizenship Studies, 13 (2): 135-151.

Kelly, D.C., 2006. "Parents’ Influence on Youths' Civic Behaviors: The Civic Context of The Caregiving Environment”. Families in Society, 87 (3): 447-455. Accessed 10th January: http://proquest.umi.com.dbgw.lis.curtin.edu.au/pqdweb?did_1127966941\&Fmt_7\&clientId_ 22212\&RQT_309\&VName_PQD.

Kisby, B. (2012). The Labour Party and Citizenship Education : policy networks and the introduction of citizenship lessons in schools. Manchester: Manchester University Press.

Kymlicka, W., and Norman, W., 2000. Citizenship in Diverse Societies. Oxford: Oxford University Press. 
Lather, P. 2006. "Paradigm Proliferation as a Good Thing to Think With: Teaching Research in Education as a Wild Profusion”, International Journal of Qualitative Studies in Education 19 (1): 35-57.

Lawy R. and Biesta G.J.J., 2006. "Citizenship as Practice: The Educational Implications of An Inclusive and Relational Understanding of Citizenship”, British Journal of Educational Studies 54 (1): 34-50.

Lister R., Smith, N., Middleton, S. and Cox L. (unpublished) ”Young People Talk About Citizenship: Empirical Perspectives on Theoretical and Political Debates”, Loughborough University. Subsequently published in the journal, Citizenship Studies [C Taylor \& Francis]. Accessed 24/04/2013 at: https://dspace.lboro.ac.uk/dspacejspui/bitstream/2134/653/1/citstudies2.pdf,

Lister, R., Smith, N., Middleton, S. and Cox, L., 2003. "Young People Talk About Citizenship: Empirical Perspectives on Theoretical and Political Debates”. Citizenship Studies, 7(2): 235253.

Lister, R., 1997. Citizenship: Feminist Perspectives. MacMillan: Basingstoke. Lister, R., 2005. Young People Talking About Citizenship in Britain. In N. Kabeer, ed. Inclusive Citizenship. London: Zed Books.

Lopes, K., Benton, T. and Cleaver, E., 2009. "Young People’s Intended Civic and Political Participation: Does Education Matter?” Journal of Youth Studies 12 (1): 1-20.

LTS (Learning and Teaching Scotland) 2002. "Education for Citizenship in Scotland: A paper for discussion and development”. Advisory Council of Learning and Teaching Scotland. Dundee: Learning and Teaching Scotland. Accessed 26 August. Http://www.ltscotland.org.uk/citizenship/managementtoolkit/planning/paper/index.asp

Lund, S., 2006. Marknad och medborgare - elevers valhandlingar gymnasiesutbildningens integrations- och differentieringsprocesser. Diss. Växjö: Växjö University Press. Maidenhead: Open University Press.

Marshall, J., 1999. "Performativity: Lyotard and Foucault through Searle and Austin”. Studies in Philosophy and Education, 18 (5): 309-317.

Marshall, T.H., 1950. Citizenship and Social Class. Cambridge: Cambridge University Press.

McLauglin, T. H. \& Halstead, J. H., 1999. "Education in Character and Virtue”. In J. M. Halstead \& T. H. McLaughlin, eds. Education in Morality. London: Routledge.

Nelson, J. \& Kerr, D., 2006. Active Citizenship in INCA Countries: Definitions, Policies, Practices and Outcomes: Final Report. England: National foundation for Educational Research. Accessed 8 May. Http://www.nfer.ac.uk/nfer/publications/QAC02/QAC02.pdf

Nicoll, K., 2008. Flexibility and Lifelong Learning: Policy Discourse and Politics.. $2^{\text {nd }}$ edn. London: Routledge.

Niklasson, L., 2007. Medborgaren som pedagogiskt projekt. Stockholm: Stockholm University Press.

Öhrn, E., Beach, D., and Lundahl, L., eds., 2011. Young People's Influence and Democratic Education. Ethnographic Studies in Upper Secondary Schools. London: Tufnell Press.

Olson M., 2012d. "What Counts as Young People's Civic Engagement in Times of Accountability? On the Importance of Maintaining Openness About Young People's Civic Engagement in Education”. Utbildning \& Demokrati [Education \& Democracy] 21 (1): 2955.

Olson M., ed., 2012c. “Theme: Citizenship Education Under Liberal Democracy. To Be or Not To Be a Properly Educated Citizen: Comments On The ICCS 2009 Study”. Utbildning \& Demokrati [Education \& Democracy] 21 (1): 17-27.

Olson, M., 2008. Från nationsbyggare till global marknadsnomad: Om medborgarskap i svensk utbildningspolitik under 1990-talet. Linköping University: LiU Press. 
Olson, M., 2009. "Democratic Citizenship - A Conditioned Apprenticeship. A Call for Destabilisation of Democracy in Education”. Journal of Social Science Education 8 (4): 7580.

Olson, M., 2012a. "Citizenship Education without Citizenship? The Migrant in EU Policy on Participatory Citizenship - Toward the Margin Through 'Strangification'”. In R. Hedke and T. Zimenkova, eds., Education for Civic and Political Participation: A Critical Approach. London: Routledge.

Olson, M., 2012b. “The European 'We': From Citizenship Policy to the Role of Education”. Studies in Philosophy and Education 31 (1): 77-89.

Olssen, M. 2003 "Foucault and Critique: Kant, Humanism and the Human Sciences", in Peters M., Olssen M. and Lankshear C., 2003. The Futures of Critical Theory: Dreams of Difference. Maryland: Rowman and Littlefield Publishers.

Osler, A. 2009 "Citizenship Education, Democracy and Racial Justice 10 Years On", Race Equality Teaching 27(3): 21-27. Accessed 7th December. http://www.academia.edu/189763/.

Osler, A. and Starkey, H., 2006. "Education for Democratic Citizenship: A Review of Research, Policy and Practice 1995-2005”. Research Papers in Education 21 (4): 433-466.

Peters, M., Blee, H., and Britton, A., eds. 2008. Global Citizenship Education: Philosophy, Theory and Pedagogy. Rotterdam, The Netherlands: Sense.

Phillips,K. R. 2002. "Spaces of Invention: Dissension, Freedom and Thought in Foucault". Philosophy and Rhetoric, 35(4) 328-344. Accessed 26 June. http://vpa.syr.edu/sites/default/files/downloads/SpacesofInvention.pdf

Potter, J. (1996). Representing Reality: Discourse, Rhetoric and Social Construction, London: Sage.

Prime Minister's Office (2000) SOU 2000:1: En uthållig demokrati: Politik för folkstyrelse för 2000-talet. Stockholm: Statsrådsberedningen.

Putnam, R., 2000. Bowling Alone: The Collapse and Revival of American Community. New York: Simon \& Schuster.

Rose, N. 1999. Powers of Freedom: Reframing Political Thought. Cambridge: Cambridge University Press.

Ross, A., 2008. A European Education. Sterling: Trentham Books.

Roth, K. and Burbules, N., eds, 2007. Changing Notions of Citizenship Education in Contemporary Nation-states. Rotterdam: Sense Publishers.

Schmeets H. and Coumans M. 2013. "The Assessment of Social Cohesion and Social Exlusion in the Netherlands", Paper prepared for the UNESCO workshop on Measuring and Assessing Inclusive Social Policies, 25-26 March, Paris.

Schulz, W., Ainley J., Fraillon J., Kerr D. and Losito B. 2010. “ICCS 2009 International Report: Civic Knowledge, Attitudes, and Engagement Among Lower-secondary School Students in 38 Countries". International Association for the Evaluation of Educational Achievement (IEA). Accessed $25 \quad$ February. Http://www.iea.nl/fileadmin/user_upload/Publications/Electronic_versions/ICCS_2009_Inter national_Report.pdf.

The National Swedish Agency for Education, 2010a. Morgondagens medborgare ICCS 2009: svenska 14-åringars kunskaper, värderingar och deltagande i internationell belysning [Citizens of Tomorrow ICCS 2009: Swedish 14-year-old's Knowledge, Values and Participation in an International Scope]. Stockholm: Fritzes.

The National Swedish Agency for Education, 2010b. Skolor som politiska arenor: Medborgarkompetens och konflikthantering. [Schools as Political Arenas: On Citizen Competence and Dealing with Conflict]. Stockholm: Fritzes.

Tursunovic, M., 2004. Fostran till demokrati: Tre sociologiska delstudier om bosniska ungdomars politiska socialisering. Sociologiska institutionen, Göteborgs universitet. 
Weller, S., 2007. Teenagers' Citzenship. Experience and Education. Abingdon: Routledge.

Werbner, P. and N. Yuval-Davis, 1999. "Introduction: Women and the New Discourse o! Citizenship.” In P.Werbner and N. Yuval-Davis, eds, Women, Citizenship and Di!ference. London and New York: Zed Books

Westheimer, J. \& Kahne, J., 2004. "What Kind of Citizen? The Politics of Educating for Democracy”, American Educational Research Journal 41 (2): 237-269.

White, M. and Hunt, A., 2000. "Citizenship: Care Of The Self, Character and Personality". Citizenship Studies, 4 (2): 93-116.

Wilson, J. 2000. “Volunteering”. Annual Review of Sociology, 26, 215-240.

Yates, M., and Youniss, J., 1998. "Youth and Politics: Theoretical Perspectives and Developmental Opportunities. Community Service and Political Identity Development in Adolescence”. Journal of Social Issues (54): 495-512.

Yeung, P., Passmore, A. and Packer, T. (2012). "Examining Citizenship Participation in Young Australian Adults: A Structural Equation Analysis”, Journal of Youth Studies, 15(1): 73-98. 